\title{
GLOBALISASI DAN RESPON PESANTREN
}

\author{
QolbiKhoiri \\ Email: qolbikhoiri@gmail.com \\ Program Pascasarjana IAIN Bengkulu
}

\begin{abstract}
The purpose of writing this article is to explain the phenomenon of globalization from its understanding of the shape and impact of globalization which then impacts Islamic boarding schools and how Islamic boarding schools respond to them. Analysis of this article is done using a literature study. The results of the analysis found that Islamic boarding schools view globalization as an age dynamic that cannot be avoided. Therefore, pesantren choose to be active while maintaining the identity and characteristics of the pesantren that function as a pioneer of reform (agent of change). The impact of globalization faced by pesantren must be made with several changes, namely changes in infrastructure and physical buildings of Islamic boarding schools. Changes involve the management and management of Islamic boarding schools. Changes in the widening of the scope and level of education in pesantren. Changes in the way the pesantren behave are no longer closed. Changes in boarding schools in the face of change will not be successful without a positive attitude from the government.
\end{abstract}

Keywords: Globalization, Islamic School Response

Abstrak: Tujuan penulisan artikel ini adalah untuk menjelaskan mengenai fenomena globalisasi dari pengertiannya hingga bentuk dan dampak globalisasi yang kemudian berdampak pada Pesantren dan bagaimana pesantren meresponnya. Analisis artikel ini dilakukan dengan menggunakan studipustaka. Hasil analisis ditemukan bahwa pondok pesantren memandang globalisasi sebagai dinamika zaman yang tidak bisa dihindari. Oleh karena itu, pesantren memilih bersikap aktif dengan tetap mempertahankan identitas dan ciri khas pesantren yang berfungsi sebagai pelopor pembaharuan (agent of change). Dampak globalisasi yang dihadapi oleh pesantren harus dilakukan dengan beberapa perubahan, yaitu perubahan menyangkut perlengkapan inprastruktur dan bangunan fisik pesantren. Perubahan menyangkut pola pengelolaan dan manejerial pesantren. Perubahan pada melebarnya cakupan dan tingkatan pendidikan di pesantren. Perubahan pada cara bersikap pesantren yang tidak lagi tertutup. Perubahan pesantren dalam menghadapi perubahan tidak akan berjalan sukses tanpa adanya sikap positif dari pemerintah.

Kata Kunci: Globalisasi, ResponPesantren

\section{Pendahuluan}

Istilah globalisasi diambil dari kata "global". Kata ini melibatkan kesadaran baru bahwa dunia adalah sebuah kontinuitas lingkungan yang

94<smiles>C1=[Te]C=[Te]=[Te]1</smiles>

NUASA Vol. XII, No. 1, Juni 2019 terkontruksi sebagai kesatuan utuh.Marshall McLuhan menyebut dunia yang diliputi kesadaran globalisasi ini global village (Desa Buana). Dunia menjadi sangat transparan sehingga eolah 
tanpa batas administrasi suatu negara. Batas-batas geografis suatu negara menjadi kabur. Globalisasi membuat dunia menjadi transparan akibat perkembangan pesat ilmu pengetahuan dan teknologi serta adanya sistem informasi satelit.

Arus globalisasi lambat laun semakin meningkat dan menyentuh hampir setiap aspek kehidupan sehari-hari. Globalisasi memunculkan gaya hidup kosmopolitan yang ditandai oleh berbagai kemudahan hubungan dan terbukanya aneka ragam informasi yang memungkinkan individu dalam masyarakat mengikuti gaya-gaya hidup baru yang disenangi.

Globalisasi menjadi kekuatan yang terus meningkat dan dapat menimbulkan aksi dan reaksi dalam kehidupan globalisai melahirkan dunia yang terbuka untuk saling berhubungan, terutama dengan ditopang teknologi informasi yang sedemikian canggih. Topangan teknologi ini pada gilirannya dapat mengubah segi-segi kehidupan, baik kehidupan material maupun kehidupan spritual. ${ }^{1}$

Namun demikian, era globalisasi dewasa ini dan di masa yang akan datang akan mempengaruhi perkembangan sosial budaya masyarakat muslim indonesia umumnya, atau pendidikan Islam, termasuk pesatren khususnya. Pesantren sebagai lembaga pendidikan, pastilah tidak bisa terhindar dari arus perubahan.Masalah yang timbul kemudian adalah sejauh mana kemampuan pesantren mendeteksi derasnya perubahan tersebut untuk kemudian tanpa gagap memberikan respon yang wajar. Dalam perjalanan waktu, watak kemandirian yang menjadi ciri khas pesantren dan sebagai pembeda dengan lembaga-lembaga pendidikan lainnya lambat laun mulai tergeser hal ini, tak lain disebabkan oleh tuntutan kontekstual yang menghadang para alumni serta pesantren itu sendiri. Sebagai contoh, misalnya dengan mendirikan pendidikan formal (madrasah/sekolah) yang berakibat pada mengendurnya tradisi, kurikulum, pola/ sistem pembelajaran pesatren.Sehingga fokus utama pengembangan adalah sekolah formalnya.Sebab ini terkait dengan layak atau tidaknya alumninya dalam kompetisi peluang kerja.Dari sinilah pergeseran itu bermula.Pesantren mau tidak mau dipaksa merespon satu kondisi dunia yang sedang berubah dengan tidak hanya fokus pada wilayah keagamaan saja.Tanpa harus menafikan motovasi ibadah dalam pencarian ilmu pengetahuan, pesatren dituntut senantiasa apresiatif sekaligus selektif dalam menyikapi dan merespon perkembangan.Dinamika kehidupan yang mengusung pragmatisme budaya yang kian mengenjala mau tidak mau membawa pesatren untuk lebih realistis dalam menyiasati fenomena tersebut.

Ruang implementasi pesantren yang pada awalnya semata berkutat pada wilayah keagamaan selanjutnya digiring pada kenyataan-kenyataan yang bahkan seringkali muncul sebagai keseharusan, yakni untuk memperluas wilayah garap di luar kerja tradisionalnya.Dunia pessantren selanjutnya harus beradaptasi dengan lingkungan sekelilingnya yang semakin pragmatik. ${ }^{2}$

Dalam konteks ini, bidang-bidang kehidupan umat manusia yang khususnya ada dalam ruang lingkup pesantren yang kurang siap dalam menghadapi era globalisasi perlu berbenah diri. Ditilik dari sejarah pendidikan Islam Indonesia, pesantren sebagai sistem pendidikan Islam tradisional memainkan peranan penting dalam membentuk kualitas sumber daya manusia (SDM) indonesia. ${ }^{3}$

Jika globalisasi adalah suatu keniscahyaan maka mau tidak mau harus dikontekskan dengan piranti-piranti globalisasi tersebut.Artinya, pendidikan pesantren sudah semestinya memiliki kepentingan untuk membentuk SDM yang siap bergulat dan bertarung untuk menghadapi arus deras globalisasi.

${ }^{1}$ Muhtarom,. Reproduksi Ulama Di Era Globalisasi, Pustaka Pelajar, Yogyakarta, 2005. Hal 44 
Apabila kita menilik pendidikan pesantren yang telah berjalan di indonesia, sungguh banyak sekali sistemnya yang harus dirombak, mulai dari cara pandang yang dipakai (Paradigma), model pembelajaran, penekanan tujuan pendidikan pesantren dan masih banyak yang lain. Dalam pusaran arus globalisasi, pada kenyataannya pendidikan pesantren secara umum belum mampu menciptakan anak didik (santri) yang kritis dan memiliki kemampuan dalam menghadapi arus globalisasi yang menindas dan mencengkram.Dalam keadaan inilah pendidikan pesantren semestinya tidak bebas nilai (valuefree), sebaliknya pendidikan pesantren harus berkepentingan untuk menciptakan santri yang kritis dan memiliki kemampuan untuk menghadapi tantang yang dihadapinya.

\section{A. Pengertian globalisasi}

Globalisasi adalah keterkaitan dan ketergantungan antar bangsa dan antar manusia diseluruh dunia melalui perdagangan, investasi, perjalanan, budaya populer, dan bentuk-bentuk interaksi yang lain sehingga batas-batas suatu negara menjadi semakin sempit. Di era globalisasi suatu proses antar individu, antar kelompok, dan antar negara saling berinteraksi, bergantung, terkait, dan memengaruhi satu sama lain yang melintasi batas negara. ${ }^{4}$

Dalam banyak hal, globalisasi mempunyai banyak karakteristik yang sama dengan internasionalisasi sehingga kedua istilah ini sering dipertukarkan. Sebagian pihak sering menggunakan istilah globalisasi yang dikaitkan dengan berkurangnya peran negara atau batas-batas negara.

Di dalam oxford advanced learner's dictionary of current englishdisebutkan bahwa menurut asal katanya, kata "globalisasi" diambil dari kata global, yang dalam bahasa inggris berarti embracing the whole of a grup of items (merangkul keseluruhan kelompok yang ada) atau maknanya ialah universal. ${ }^{5}$ Achmad suparman menyatakan globalisasi adalah suatu proses menjadikan sesuatu (benda atau prilaku) sebagai ciri dari setiap individu di dunia ini tanpa dibatasi oleh wilayah. Globalisasi belum memiliki definisi yang mapan, kecuali sekedar definisi kerja (working definition), sehingga bergantung dari sisi mana orang melihatnya. Ada yang memandangnya sebagai sustu proses sosial, atau proses sejarah, atau proses alamiah yang akan membawa seluruh bangsa dan negara di dunia makin terikat satu sama lain, mewujudkan satu tatanan kehidupan baru atau kesatuan ko-eksitensi dengan menyingkirkan batas-batas geografis, ekonomi dan budaya masyarakat. ${ }^{6}$

Di sisi lain, ada yang melihat globalisasi sebagai sebuah proyek yang di usung oleh negaranegara adikuasa, sehingga bisa saja ornag memiliki pandangan negatif atau curiga terhadapnya, dari sudut pandang ini, globalisasi tidak lain adalah kapitalisme dalam bentuk yang paling mutakhir. Negara-negara yang kuat kaya praktis akan mengendalikan ekonomi dunia dan negara-neaga kecil makin tidak berdaya karena tidak mampu bersaing. Sebab, globalisasi cendrung berpengaruh besar terhadap perekonomian dunia, bahkan berpengeruh terhadap bidangbidang lain seperti budaya dan agama.Teodere lepite merupakan orang yang pertama kali menggunakan istilah globalisasi pada tahun1985 dan kini telah menjadi selogan magis di dalam setiap topik pembahasan. ${ }^{7}$

Scholte melihat bahwa ada beberapa definisi yang dimaksudkan orang dengan globalisasi : ${ }^{8}$

1. Internasionalisasi: globalisasi diartikan sebagai meningkatnya hubungan internasional dalam hal ini masing-masing negara

2Djohar.Pengantar Transformatif Teras. Yogyakarta, 2008, hal. xv

${ }^{3}$ Nurcholis Madjid, Islam Kerakyatan Dan Keindonesiaan, Cet Ke-3, Mizan, Bandung, 1996, Hal. 222

${ }^{4} \mathrm{Http}: / /$ Id. Wikipedia.Org/Wiki/Globalisasi

${ }^{5}$ Abdullah Idi \& Toto Suharto.Revitalisasi Pendidikan Islam, Yogyakarta, Et 3. Pt Tiara Wacana. 2006 
tetap mempertahankan identitasnya masing-masing, namun menjadi semakin tergantung satu sama lain.

2. Liberalisasi: globalisasi juga diartikan dengan semakin diturunkan batas antar negara, misalnya hambatan tarik ekpor inpor, lalu lintas devisa, maupun migrasi.

3. Universalisasi: globalisasi juga digambarkan sebagai semakin tersebarnya hal material maupun imaterial keseluruh dunia. Pengalaman disitu lokalitas dapat menjadi pengalaman seluruh dunia.

4. Westernisasi: westernisasi adalah salah satu bentuk dari universalisasi dengan semakin menyebarnya fikiran dan budaya dari barat sehingga menglobal.

5. Hubungan transplanetari dan suprateritorialitas: arti kelima ini berbeda dengan keempat definisi diatas. Pada empat definisi pertama, masing-masing negara masih mempertahankan status ontologinya. Pada pengertian yang kelima, dunia global memliki status ontologi sendiri, bukan sekedar gabungan negara-negara.

Globalisasi memiliki beberapa ciri yang menandakan semakin berkembangnya fenomena di dunia, yaitu : 9

1. Hilir mudiknya kapal-kapal pengankut barang antar negara menunjukkan keterkaitan antar manusia di seluruh dunia.

2. Perubahan dalam konstantin ruang dan waktu. Perkembangan barang-barang seperti telpon genggan. Televisi satelit, dan internet menunjukkan bahwa komunikasi global terjadi sedemikian cepatnya, sementara melalui pergerakan masa semacam turisme memungkinkan kita merasakan banyak hal dari

${ }^{6}$ Abdullah Idi \& Toto Suharto Revitalisasi Pendidikan...

${ }^{7}$ Abdullah Idi \& Toto Suharto.Revitalisasi Pendidikan...

${ }^{8}$ Abdullah Idi \& Toto Suharto.Revitalisasi Pendidikan...

${ }^{9}$ Abdullah Idi \& Toto Suharto.Revitalisasi Pendidikan... budaya yang berbeda.

3. Pasar dan produksi ekonomi di negara-negara yang berbeda menjadi saling bergantung akibat dari pertumbuhan perdagangan internasional, peningkatan pengaruh perusahaan multinasional, dan dominasi organisasi semacam Word Trade Organisation (WTO).

4. Peningkatan interaksi kultural melalui perkembangan media masa (terutama televisi, film, musik, dan transmisi berita dan olah raga internasional). Saat ini, kita dapat mengkonsumsi dan mengalami gagasan dan pengalaman baru mengenai hal-hal yang melintas beraneka ragam budaya, misalnya dalam bidang fashion, literatur dan makanan.

5. Meningkatnya masalah bersama, misalnya pada bidang lingkungan hidup, krisis multinasional, implasi regional dan lain-lain.

Kenendy dan cohen menyimpulkan bahwa transformasi ini telah membawa kita pada globalisme, sebuah kesadaran dan pemahaman baru bahwa dunia adalah satu. Giddens menegaskan bahwa kebanyakan dari kita sadaar bahwa sebenarnya diri kita turut andil bagian dalam sebuah dunia yang harus berubah tanpa terkendali yang ditandai dengan selera dan rasa ketertarikan akan hal sama, perubahan dan ketidak pastian, serta kenyataan yang mungkin terjadi. Sejalan dengan itu kita bisa menyebutkan bahwa globalisasi sebagai zaman transformasi sosial. ${ }^{10}$

\section{B. KECENDRUNGAN-KECENDRUNGAN GLOBAL}

Seiring dengan berkembangnya aktifitas manusia, era globalisasi pun mengandung banyak kecendrungan, diantaranya adalah $:^{11}$

1. Informasi yang cepat, sebutan era informasi menggaris bawahi bahwa peran strategis dari informasi, yakni bahwa kendali atas dunia benar-benar ditentukan oleh pihak yang 
98

menguasai informasi.

2. Perkembangan industri, perubahan dan perkembangan industri merupakan kemajuan bangsa-bangsa di dunia, dan ini tidak dapat dilepaskan dari pergeseran konsentrasi sumber impestasi.

3. Perubahan demografi, demografi merupakan salah satu kecendrungan lain di era globalisasi. Kini, penduduk dunia mengalami pertumbuhan sekitar dua kali lipat dari jumlah penduduk tahun 1950 yang berjumlah 2,5 miliar.

4. Perkembangan ekonomi, globalisasi ekonomi mengandung makna bahwa semua hambatan pada transaksi perdagangan barang dan jasa, pergerakan manusia, dan investasi antar negara dikurangi secara bertahap hingga terhapus dalam jangka waktu tertentu.

5. Perubahan sistem nilai, globalisasi akan membawa dampak pada pergeseran nilai. Pergeseran nilai yang dimaksud khususnya adalah nilai-nilai keagamaan, tidak terkecuali nilai-nilai agama islam.

\section{DAMPAK POSITIF DAN NEGATIF GLO- BALISASI}

Globalisasi mempengaruhi hampir semua aspek yang ada di masyarakat, baik ekonomi, sosial, budaya dan pendidikan.Globalisasi ini memiliki dampak positif dan negatif. ${ }^{12}$ Dampak positif globalisasi antara lain:

1. Mudah memperoleh informasi dan ilmu pengetahuan

2. Mudah melakukan komunikasi

3. Cepat dalam bepergian (mobilitas tinggi)

4. Menumbuhkan sikap kosmopolitan dan toleran

5. Memacu untuk meningkatkan kualitas diri

6. Mudah memenuhi kebutuhan

${ }^{10}$ Anthony Giddes, Runaway World. Bagaimana Globalisasi Merombak Kehidupan Kita. Terj Andry Kristiawan Dan Yustina Koen S. Jakarta Pustaka Utama, 2001

${ }^{11}$ Abdullah Idi \& Toto Suharto.Revitalisasi Pendidikan... Hlm. 104-106
Adapun dampak negatif globalisasi antara lain:

1. Informasi yang tidak tersaring

2. Prilaku konsumtif

3. Pendewaan aspek rasio yang berlebihan

4. Membuat sikap menutup diri, berfikir sempit.

5. Pemborosan pengeluaran dan meniru perilaku yang buruk

6. Mudah terpengaruh oleh hal yang tidak sesuai dengan kebiasaan atau kebudayaan suatu negara

\section{PENGERTIAN PESANTREN}

Pesantren merupakan lembaga pendidikan islam tertua dan dianggap sebagai budaya asli indonesia (indigenous) serta memiliki akar yang sangat kuat dalam kehidupan masyarakat. Kata pesantren berasal dari kata santri yang mendapat awalan pe dan akhiran an yang berarti "tempat para santri". Terkadang juga dianggap sebagai kata san (manusia baik) dengan suku kata tra (suka menolong), sehingga kata pesantren dapat berarti "tempat pendidikan manusia baik-baik". Keberadaan sistem pendidikan pesantren bahkan telah ada jauh sebelum kedatangan islam ke negeri ini, yaitu pada masa hindu-budha. ${ }^{13}$ Pada saat itu pesantren merupakan lembaga keagamaan yang berfungsi mencetak elit agama hindu dan budha. Pondok pesantren berasal dari dua kata: kata pondok berasal dari bahasa arab "funduk" berarti hotel atau asrama. ${ }^{14}$ sedangkan kata pesantren berasal dari kata santri yang diberi awalan "pe" dan akhiran "an" yang berarti tempat tinggal para santri. ${ }^{15}$

Keduanya memiliki konotasi yang sama, yakni menunjukkan pada suatu kompleks untuk kediaman dan belajar para santri. Jadi pondok

${ }^{12}$ Sri andri astuti, Pesantren Dan Globalisasi Jurnal Tarbawiyah volume 11 nomor 1 edisi januari-juli 2015

${ }^{13}$ Azyumardi azra.Pendidikan Islam: Tradisi Dan Modernisasi Menuju Milenium Baru. Jakarta. logos. 1999, hal. 108

${ }^{14}$ Abdullah idi "Etika Pendidikan: Keluarga Sekolah Dan Masyarakat" dalam Zamakhsyari Dhofier, Tradisi Pesantren: Studi Tentang Pandangan Kyai. Jakarta. Ip3es, 1982. Hal 44-60

${ }^{15}$ Abdullah idi “Etika Pendidikan... hlm. 152 
pesantren dapat diartikan asrama tempat tinggal para santri.

Sedangkan kata santri berasal dari bahasa tamil (india), yaitu sastra yang berarti ilmuan hindu yang pandai menulis. Maksudnya, pesantren adalah tempat bagi orang-orang yang panai membaca dan menulis. Hal ini dikaitkan dengan anggapan bahwa pesantren dimodifikasi dari pura hindu. Menurut karel a. Stenbrink, secara termonologis, dapat dijelaskan pesantren, dilihat dari segi bentuk dan sistemnya, berasal dari india. Sebelum proses penyebaran islam di indonesia, sistem tersebut telah dipergunakan secara umum untuk pendidikan dan pengajaran agama hindu di jawa. Setelah islam masuk dan tersebar di jawa, sistem tersebut kemudia diambil oleh islam. istilah pesantren sendiri seperti halnya mengaji bukanlah berasal dari istilah arab, melainkan dari india. Demikian juga istilah pondok, langgar di jawa, surau di minangkabau dan rangkang di acah bukanlah istilah arab, melainkan istilah yang terdapat di india. ${ }^{16}$

\section{E. KOMPONEN DASAR PESANTREN}

Pesantren memiliki lima elemen dasar yang membedakan pesantren dengan lembaga pendidikan lainnya. ${ }^{17}$ Lima elemen dasar pesantren tersebut adalah:

1. Kiay. Kiay merupakan tokoh sentral dalam pesantren yang memberikan pengajaran. Kiay memiliki peran yang paling esensial dalam pendirian, pertumbuhan dan perkembangan sebuah pesantren. Sebagai pemimpin pesantren, keberhasilan pesantren banyak bergantung pada keahlian dan kedalaman ilmu, karisma, wibawa serta keterampilan kiay. Dalam konteks ini, pribadi kiay sangat menentukan, sebab ia adalah

${ }^{16}$ Karel A Steenbrink. Pesantren, Madrasah, Sekolah: Pendidikan Islam Dalam Kurun Moderen. Jakarta Lp3es. 1994. Hal 20.

${ }^{17}$ Zamakhsyari Dhofier. Tradisi Pesantren: Studi Tentang Pandangan Kyai. Jakarta. Lp3es. 1982. Hal. 44-60 tokoh central dalam pesantren. Tegasnya, kiay adalah tempat bertanya tau sumber referensi, tempat penyelsaikan segala urusan dan tempat meminta nasehat dan patwa.

2. Santri. Merupakan elemen yang penting sekali dalam perkembagan sebuah pesantren. Karena idealnya, langkah pertama dalam tahap-tahap membangun pesantren adalah harus ada murid yang datang untuk belajar dari seorang alim. Jika murid tersebut sudah menetap di rimah seorang alim, baru seorang alim itu disebut kiay dan mulai membangun fasilitas yang lebih lengkap untuk pondoknya. Santri biasanya terdiri dari dua kelompok yaitu santri kalong dan santri mukim. Santri kalong adalah santri yang tidak menetap di dalam pondok. Setelah selesai mengikuti suatu pelajaran di pesantren, santri pulang ke rumah masingmasing.

3. Masjid. Masjid merupakan pusat kegiatan beribadah. Disamping berfungsi sebagai tempat melakukan shalat berjemaah, masjid juga berfungsi sebagai tempat belajar mengajar. Biasanya waktu belajar mengajar di pesantren berkaitan dengan waktu shalat berjamaah, baik sebelum dan sesudahnya. Dalam perkembangannya, sesuai dengan perkembangan jumlah santri dan tingkatan pelajaran dibangun tempat atau ruangan khusus untuk khalaqah. Namun demikian, masjid-masjid tetap digunakan sebagai tempat belajar mengajar. Pada sebagian pesantren, masjid juga berfungsi sebagai tempat i'tikaf dan melaksanakan latihan-latihan atau suluk dan berzikir maupun amalanamalan lainnya.

4. Pondok. Istilah pondok berasal dari bahasa arab funduk yang artinya hotel atau asrama. Dalam konteks pesantren, pondok atau asarama adalah tempat tinggal sederhana yang merupakan tempat tinggal kiay ber- 
sama para santrinya. Tanpa memperhatikan jumlah santrinya, asrama santri putra selalu dipisahkan dengan asrama santri putri. Sistem asrama ini merupakan ciri khas tradisi pesantren yang membedakan sistem pendidikan pesantren dengan sistem pendidikan lainnya. Biasanya komplek sebuah pesantren, memiliki gedung-gedung selain dari asrama santri dan rumah kiay, termasuk perumahan ustad, gedung madrasah, lapangan olah raga, kantin, dengan adanya tri pusat pendidikan di pesantren sangat mendudukng penerapan kurikulum selama 24 jam dan mempunyai kelebihan dibanding non pesantren, yaitu kemampuan koordinasi yang efisien, karena seluruh fungsionaris selalu berada di kampus dan kemampuan membentuk dan menjaga anak didik dari pengaruh negatif lingkungan dengan memanfaatkan apa yang ada di pondok sebagai sarana pendidikan serta adanya masjid yang berfungsi sebagai pusat kegiatan santri dan kiay ebagai figur sentral.

5. Kitab-kitab islam klasik. Kitab-kitab agama islam yang klasik dengan tulisan arab dan bahasa melayu kuno atau dalam bahasa arab, biaanya dikarang oleh ulama-ulama islam (arab) pada zaman pertengahan. Isinya mencakup macam-macam ilmu pengetahuan agama islam dan bahasa arab. Dalam tradisi pesantren, kitab-kitab islam klasik sering disebut kitab kuning karena warna kertas pada isi kitab kebanyakan berwarna kuning. Pada masa lalu, pengajaran kitab-kitab islam klasik merupakan satusatunya pengajaran formal yang diberikan dilingkungan pesantren. Saat ini mayoritas pesantren telah mengakomodasi pengajaran ilmu pengetahuan umum sebagai suatu bagian yang juga penting dalam pendidikan pesantren. Namun pengajaran kitab-kitab islam klasik masih menjadi prioritas utama.
Biasanya, dalam pengajaran kitab-kitab klasik dilakukan secara bertahap, diawali dengan kitab-kitab yang sederhana, kemudian dilanjutkan pada kitab-kitab yang lebih mendalam. Setidaknya, ada 8 macam bidang pengetahuan yang diajarkan dalam kitab-kitab klasik, yaitu nahwu dan sahraf, fikih, ushul fikih, hadis, tafsir, tauhid, tasawuf dan akhlak, dan cabang-cabang lainnya, seperti tarikh dan balagh. Semua jenis kitab ini dapat digolongkan kedalam kelompok menurut tingkat ajarannya, misalnya tingkat dasar, menegah dan lanjut. Pesantren tidak hanya berfungsi sebagai lembaga pendidikan, tetapi juga berfungsi sebagai lembaga sosial dan penyiaran keagamaan. Ebagai lembaga pendidikan, pesantren menyelenggarakan pendidikan formal (madrasah, sekolah umum, perguruan tinggi) dan non formal. Sebagai lembaga sosial, pesantren menampung anak-anak dari segala lapisan masyarakat muslim tanpa membeda-bedakan status sosial, menerima tamu yang datang dari masyarakat umum dengan motif berbeda-beda. Sebagai lembaga penyiaran agama islam, masjid pesantren juga berfungsi sebagai masjid umum yakni sebagai tempat belajar agama dan ibadah bagi para jamaah. ${ }^{18}$

\section{F. UNSUR SISTEM PENDIDIKAN PESAN TREN}

mastuhu ${ }^{19}$ mengungkapkan terdapat sejumlah unsur sistem pendidikan pesantren:

1. Adanya tujuan

2. Filsafat dan tata nilai

3. Struktur organisasi pesantren: status organ-

${ }^{18}$ Samsul Nizar. Sejarah Pendidikan Islam Menelusuri Jejak Sejarah Pendidikan Era Rasulullah Sampai Indonesia.Jakarta, kencana. 2009. Hal. 288

${ }^{19}$ Abdullah idi, "Etika Pendidikan: Keluarga, Sekolah Dan Masyarakat" dalam Mastuhu,Dinamika Sistem Pendidikan Pesantren Dan Madrasah. Fakultas tarbiyah IAIN Wali Songo Semarang bekerja sama dengan Pustaka Pelajar. Yogyakarta. 1992. Hlm. 174-175 
Qolbikhoiri| Globalisasi dan Respon Pesantren 101

isasi, status kelembagaan, gaya kepemimpinan dan suksesi kepemimpinan

4. Lingkungan kehidupan pesantren

5. Kiai dan ustadz

6. Santri

7. Pengurus/mudabbirah/musyrif

8. Interaksi pelaku

9. Kurikulum dan sumber belajar

10. Proses belajar mengajar dan evaluasi pembelajaran

11. Pengelolaan dan dana

12. Sarana dan alat-alat pendidikan

\section{G. TIPOLOGI PESANTREN DALAM MERE- SPON GLOBALISASI}

Secara umum ada tiga pola sikap pesantren dalam menghadapi arus globalisasi, diantaranya adalah. ${ }^{20}$

1. Menolak secara total. Sikap ini dibuktikan dengan menutup diri secara total terhadap modernisme, baik pola pikir maupun sistem pendidikan dengan cara menjaga otentisitas tradisi dan nilai pesantren secara ketat, baik dalam bentuk simbol maupun substansi. Pesantren tipe ini dinamakan pesantren tradisional atau salafiyah yaitu pesantren yang masih tetap mempertahankan bentuk aslinya dengan semata-mata mengajarkan kitabyang ditulis oleh ulama-ulama abad ke-15 dengan menggunakan bahasa arab. Pola pengajarannya menggunakan sistem "halaqah". Artinya diskusi untuk memahami isi kitab, bukan ubtuk mempertanyakan kemungkinan benar salahnya yang diajarkan oleh kitab, tetapi untuk memahami apa maksud yang diajarkan oleh kitab, karena mereka memahami bahwa kiai tidak mungkin mengajarkan hal-hal yang salah serta yakin bahwa kitab yang dipelajari benar. $^{21}$

Pesantren model salafiyah hanya mengajarkan pelajaran-pelajaran keagamaan tanpa dikaitkan dengan pengajaran keduniawian, apak- ah alumninya akan diarahkan menjadi apa, yang penting alumninya mempunyai pemahaman yang kuat dalam keagamaan dan kemudian dapat bermanfaat bagi masyarakat setempat. $^{22}$

Pola ini diterapkan oleh pesantren tegal rejo di magelang, mathaliul palah di kajenpati, pesantren lirboyo kediri (hm putra dan putri). Pesantren-pesantren ini tidak memasukkan pelajaran umum dan tetap menggunakan pola bandungan, sorogan, wetonan dan hafalan dalam metode pendidikannya. Mereka juga menolak penerapan formalisme pesantren sebagaimana tercermin dalam skb tiga mentri.Tujuan pendidikannya adalah untuk meninggikan moral, melatih, dan mempertinggi semangat, menghargai nilai-nilai spiritual dan kemanusiaan, mengajarkan sikap dan tingkah laku yang jujur dan bermoral serta menyiapkan para santri untuk hidup dan bersih hati. ${ }^{23}$ Umumnya pesantren tipe ini masih eksis di daerah-daerah pedalaman atau pedesaan.

2. Menerima modernisme secara total, baik pemikiran, model maupun referensinya. Pesantren tipe ini dinamakan pesantren moderen atau khalifiah. Zamakhsyari dehofir mengatakan bahwa peantren berusaha mengintegrasikan secara penuh sistem klasikal dan sekolah ke dalam pondok pesantren. Pengajian kitab-kitab klasik tidak lagi menonjol, bahkan ada yang hanya sekedar pelengkap yang diubah menjadi mata pelajaran atau bidang studi.

Pola pesantren seperti ini tercermin dalam pesantren modern darussalam gontor, pesant-

${ }^{20}$ Ngatawi El-Zastrow. Dialog Pesantren. Barat Sebuah Transformasi Dunia Pesantren Dalam Jurnal Pondok Pesantren Mihrab Komunikatif Daam Berwacana. Edisi 1 Tahun Iv 2006, Hal 5

${ }^{21}$ Abdullah Idi. Etika Pendidikan Sekolah, Keluarga Dan Masyaraka Dalam Mastuhu Dinamika Sistem Pendidikan Pesantren, Jakarta: Inis, 1994 Hlm 61

${ }^{22}$ Mundzier Suparta. Revitalisasi Pesantren: Pasang Surut Peran Dan Fungsi. Dalam Bina Pesantren Media Informasi \& Artikulasi Dunia Pesantren. Edisi 02/Tahun 1/Nopember 2006. Hal 24 
ren walisongo ngabar ponorogo, pesantren pabelan magelang dan sejenisnya.Pesantren tipe ini telah mengalami transformasi yang sangat signifikan baik dalam sistem pendidikannya maupun unsur-unsur kelembagaannya.Disini tidak saja diajarkan nilai-nilai agama dengan referensi kitab klasik, tetapi juga diajarkan pengetahuan umum.Kurikulum yang digunakan juga kurikulum umum, tidak lagi kurikulum pesantren yang menggunakan kitab muktabar.Materi pelajaran dan metodenya sudah sepenuhnya menganut sistem modern.Pengembagan bakat dan minat sangat diperhatikan sehingga para santri dapat menyalurkan bakat dan hobinya secara proposional. Sistem pengajaran dilaksanakan dengan forsi sama antara pendidikan agama dan umum, penguasaan bahasa asing (bahasa arab dan inggris) sangat ditekankan.

3. Menerima modernisme secara selektif.Pesantren tipe ini disebut juga dengan pesantren komfrehensif adalah penggambungan kedua pesantren tersebut di atas. Pada pola ini ada proses kreatif dari kalangan pesantren dalam menerima modernisme. Pesantren ini menerima sebagian modernisme kemudian dipadu dengan tradisi pesantren. Pola ini nampak pada mayoritas pesantren nu di jombang, peserta pesantren tebu ireng, pesantren darul ulum dan juga beberapa pesantren nu di krapiak yogyakarta dan beberapa pesantren lainnya. Pada pola ini pesantren menerapkan metode modern dalam sistem pengajaran, memasukkan refernsi-referensi pengetahuan umum dalam pendidikan, namun kitab-kitab klasik dengan pola pengajaran ala pesantren tetap diterapkan. Manajemen dan administrasi sudah mulai ditata secara modern mekipun sistem tradisionalnya masih dipertahankan. Sudah ada semacam yayasan, biaya pendidi- kan sudah dipungut. Alumni pesantren tipe ini cendrung melanjutkan pendidikannya ke sekolah atau perguruan tinggi formal.

Dari ketiga tipe pesantren di atas pesantren modern yang selalu menyesuaikan dengan perkembangan zaman, tuntutan umat, dan perkembangan ilmu pengetahuan serta karakter adat yang ada. Sedangkan pada pesantren tipe ke tiga, ada yang menonjol salafnya dan ada yang fifti-fifti.

\section{H. PENGEMbangan PESANTREN DI ERA GLOBALISASI}

Ditengah terpaan arus globalisasi, banyak pakar menyatakan dunia makin kompleks dan saling ketergantungan. Perubahan yang akan terjadi dalam bentuk non linier, tidak bersambung, dan tidak bisa diramalkan. Masa depan merupakan suatu ketidak sinambungan. Kita memerlukan pemikiran ulang dan rekayasa ulang terhadap masa depan yang akan dilewati. Kita berani tampil dengan pemikiran terbuka dan meninggalkan cara-cara lama yang tidak produktif.Penomena globalisasi banyak melahirkan sifat individualisme dan pola hidup materialistik yang kian mengental.Disinilah keunikan pesantren masih konsisten dengan menyuguhkan suatu sistem, pendidikan yang mampu mejembatani kebutuhan fisik (jasmani) dan kebutuhan mental spiritual (rohani) manusia.Dalam mengahadapi tantangan yang semakin kompleks dilingkungan masyarakat, pesantren harus berani tampil dan mengembangkan dirinya sebagai pusat keunggulan.Pesantren tidak hanya mendidik santri agar memiliki keunggulan jiwa (taqwimu al nufus), jalan hidup yang lurus, budi pekerti yang mulia, tetapi juga santri yang dibekali dengan berbagai disiplin ilmu ketrampilannya, guna dapat diwu-

${ }^{23}$ Haidar Putra Daulay. Pendidikan Islam Dalam Sistem Pendidikan Nasional Di Indonesia. Jakarta. kencana. 2004, hal 28

${ }^{24}$ Zamakhsyari Dhofier. Tradisi Pesantren: ...hlm 44

${ }^{25}$ Zamakhsyari Dhofier. Tradisi Pesantren: ... 
Qolbikhoiri| Globalisasi dan Respon Pesantren 103

judkan dan mengembangkan segenap kualitas yang dimilikinya.Untuk mencapai tujuan tersebut, para santri harus dibekali nilai-nilai keislaman yang dipadukan dengan ketrampilan.Tuntutan globalisasi tidak mungkin dihindari.Salah satu langkah yang bijak adalah mempersiapkan pesantren tidak "ketinggalan kereta" agar tidak kalah dalam persaingan.Pada tataran ini masih banyak pembenahan dan perbaikan yang harus dilakukan oleh pesantren.

Paling tidak tiga hal yang harus digarap oleh pesantren yang sesuai dengan jati dirinya. ${ }^{26}$

1. Penegasan identitas bahwa pesantren sebagai lembaga pendidikan pengkaderan ulama. Fungsi ini tetap harus melekat pada pesantren, karena pesantren adalah satu-satunya lembaga pendidikan yang melahirkan ulama. Namun demikian, tuntutan modernisasi dan globalisasi mengharuskan ulama memiliki kemampuan lebih, kapasitas intelektual yang memadai, wawasan, akses pengetahuan dan informasi yang cukup serta responsif terhadap perkembangan dan perubahan.

2. Pesantren sebagai lembaga pusat pengembagan ilmu pengetahuan, khususnya agama islam. Pada tatanan ini, pesantren masih dianggap lemah dalam penguasaan ilmu dan metodologi. Pembekalan ilmu dan ketrampilan dapat ditempuh dengan mempelajari tradisi ilmu pengetahuan agama dan penggalian dari teknologi ketrampilan umum. Karena, tradisi keilmuan dan kebudayaan islam sangat kaya. Bahwasannya agama islam bukan mengganti ilmu dan kebudayaan, bahkan bukan pula musuh ilmu dan kebudayaan. Agama islam merupakan bingkai ilmu dan kebudayaan, sumbu untuk ilmu dan kebudayaan, begitu pula sebagai metode ilmu dan kebudayaan dan membatasi bing-

${ }^{26} \mathrm{M}$ Ibad El-Mun'im.Daurah Ulama Dan Penguatan Peran Pesantren Dalam Bina Pesantren Media Informasi \& Artikulasi Dunia Pesantren.Edisi 01/Tahun 1/ Oktober 2006.Hal. 52 kai dan poros yang mampu memberi hukum (peraturan) bagi segala kehidupan. Disinilan peran pesantren perlu ditingkatkan.

3. Dunia pesantren harus mampu menempatkan dirinya sebagai transformasi, motofator dan inofator. Sebagai salah satu komponen masyarakat, pesantren memiliki kekuatan dan "daya tawar" untuk melakukan perubahan yang berarti. Menyiasati perubahan, pesantren tidak serta merta melakukan perombakan seluruh sturktur dan tradisi pendidikan pesantren. Pesantren dengan segala keunikannya mutlak dipertahankan sekaligus pada saat yang sama modifikasi dan impropisasi pun diupayakan. Modifikasi dan impropisasi yang dilakukan pesantren semestinya hanya terbatas pada aspek teknis oprasionalnya, bukan substansi pendidikan pesantren itu sendiri. Sebab jika impropisasi itu menyangkut substansi pendidikan, maka pesantren yang telah mengakar ratusan tahun lamanya akan tercerabut dan kehilangan elanpital sebagai penompang moral yang menjadi citra utama pendidikan pesantren. Teknis oprasional yang dimaksud bisa berwujud perencanaan pendidikan yang lebih komprehensif, pembenahan kurikulum pesantren yang mudah dicernakan, dan tentu saja adalah skala prioritas dalam pendidikan.

Selain itu, pembenahan infrastruktur pesantren patut dijadikan agenda bersama, setidaknya ini dimaksudkan untuk mengubah citra pesantren yang kumuh dan terkesan terbelakang.

\section{EKSISTENSI PESANTREN DI ERA GLO- BALISASI}

Eksistensi pesantren dalam menyikapi perkembangan zaman, tentunya memiliki komitmen untuk tetap menyuguhkan pola pendidikan yang mampu melahirkan sumber daya manusia (sdm) yang handal kekuatan otak (berfikir), hati 
(keimanan) dan tangan (ketrampilan), merupakan modal utama untuk membentuk pribadi santri yang mampu menyeimbangi perkembagan zaman. Berbagai kegiatan keterampilan dalam bentuk pelatihan/workshop (daurah) yang lebih memperdalam ilmu pengetahuan dan keterampilan kerja adalah upaya untuk menambah wawasan santri dibidang sosial, budaya dan ilmu praktis.Ini merupakan salah satu trobosan konkret untuk mempersiapkan individu santri di lingkungan masyarakat.Pesantren telah mulai menjajaki dan melakukan perubahan signifikan setidaknya pada 4 aspek. ${ }^{27}$

1. Perubahan menyangkut perlengkapan inprastruktur dan bangunan fisik pesantren. Sebagaimana dijumpai disebagian besar pesantren pada saat ini. Gedung-gedung baru dengan perangkat fasilitas yang menopang kelangsungan pendidikan, semisal komputer,laboratorium bahasa, perpustakaan, sarana olahraga, sarana kesehatan, dan semacamnya mulai tersedia. Bahkan juga dilengkapi dengan koprasi pesantren yang menjadi aset ekonomi para santri dan pesantren dalam mengembangkan daya tahannya.

2. Perubahan menyangkut pola pengelolaan dan menejerial pesantren. Terbentuknya yayasan dengan manajemen terbuka (open magement) memungkinkan pesantren mengubah pola kepemimpinan tunggal yang mengacu pada figur kiai tertentu pada pola kepemimpinan kolektif. Pola majemen semacam ini tidak menafik otoritas kiai yang menjadi ciri utama pesantren, terlembaga dalam dewan pengasuh. Sedangkan yayasan yang berwenang dalam pembenahan oprasionalisasi pendidikalisasi diserahkan pada kiai yunior dengan dibantu sejumlah santri.

${ }^{27}$ Mashudi Abdurrahman. Memelihara Tradisi Memperbaharui Pendidikan Pesantren Dalam Bina Pesantren Media Informasi \& Artikulasi Dunia Pesantren, Edisi 01/Tahun 1/Oktober 2006. Hal 24
Dalam konteks ini, diversifikasi wewenang relatif merata, dan keputusan tidak muncul sepihak melainkan melalui mekanisme musyawarah seluruh komponen yang ada kepengurusan yayasan.

3. Perubahan pada melebarnya cakupan dan tingkatan pendidikan di pesantren. Disamping bertahan dengan pola pengajaran semisal sorogan dan wetonan, pesantren juga membuka ruang pada pendidikan dengan sistem klasikal dan berjenjang dari jenjang pendidikan taman kanak-kanak hingga perguruan tinggi. Bahkan, tidak sedikit pesantren yang mulai membuka jenjang pendidikan yang berorientasi pada pendidikan umum semisal smp, sma dan semacamnya. Dalam konteks ini, pesantren tidak hanya mempertajam pengetahuan agama yang menjadi ciri pendidikannya, tetapi juga melengkapinya dengan disiplin keilmuan lain yang bisa menopang pengetahuan agamanya.

4. Perubahan pada cara bersikap pesantren yang tidak lagi tertutup. Pesantren mulai membuka diri pada perubahan-perubahan selama menompang kualitas keilmuan pesantren. Upaya pesantren membuka pendidikan yang berorientasi fokasional melalui sanggar-sanggar keterampilan dan kursuskursus dalam kegiatan ekstra kurikuler pesantren merupakan salah satu wujudnya. Dalam konteks ini, kita jumpai sejumlah pesantren yang membuka lembaga-lembaga kursus semisal kursus menjahit, kursus komputer, kursus fotografi dan lain-lain.

5. Perubahan pesantren dalam menghadapi perubahan tidak akan berjalan sukses tanpa adanya sikap positif dari pemerintah. Pemerintah melalui kementrian agama harus memberikan perhatian yang lebih dengan menyediakan sarana prasarana, pembinaan dalam manajemen dan sebagainya. 
Dengan melakukan sejumlah perubahanperubahan, pesantren saat ini dan tentu dimasa yang akan datang, bisa hadir sebagai lembaga pendidikan yang masih digemari masyarakat. Pesantren menjadi lembaga favorit dalam masyarakat.

\section{Kesimpulan}

Dunia pondok pesantren memandang globalisasi sebagai dinamika zaman yang tidak bisa dihindari.Globalisasi dengan segala akibatnya tidak perlu ditakuti, namun harus disikapi secara serius.Apapun sikap masyarakat atau komunitas, termasuk pesantren, globalisasi tetap bergulir memasuki relung-relung kehidupan masyarakat. Oleh karena itu, pesantren memilih bersikap aktif dengan tetap mempertahankan identitas dan ciri khas pesantren yang berfungsi sebagai pelopor pembaharuan (agent of change).

Setiap era pastimengandung plus dan munus. Tak terkecuali era globalisasi.Oleh karena itu, pesantren mencoba mengambil hal-hal positif dan membuang sesuatu yang negatif dalam globalisasi. secara individual, dalam merespon globalisasi, setiap pesantren harus memperkirakan kesulitan yang dihadapinya, dan kemudia memilih salah satu diantara tawaran yang telah digolongkan diatas, apakah dengan menolak secara total modernisme, menerima atau dengan jalan tawasuth yaitu menerima dengan selektif. Pesantren itu diajak berlatih untuk mengadakan penilaian sendiri atas kemampuan sendiri, melalui pilihan yang akan digarap. Hanya dengan sistem bertahap pesantren dapat digugah perhatiannya secara konkret terhadap kebutuhan akan perbaikan yang bersifat menyeluruh.

\section{Daftar Pustaka}

Abdullah Idi \& Toto Suharto.Revitalisasi Pendidikan Islam. Yogyakarta, Et 3. Pt Tiara Wacana. 2006

"Etika Pendidikan: Keluarga Sekolah Dan
Qolbikhoiri| Globalisasi dan Respon Pesantren 105

Masyarakat" dalam Zamakhsyari Dhofier, Tradisi Pesantren: Studi Tentang Pandangan Kyai. Jakarta. lp3es, 1982.

, "Etika Pendidikan: Keluarga, Sekolah Dan Masyarakat" dalam Mastuhu, Dinamika Sistem Pendidikan Pesantren Dan Madrasah. Fakultas Tarbiyah IAIN Wali Songo Semarang bekerja sama dengan Pustaka Pelajar. Yogyakarta. 1992

. Etika Pendidikan Sekolah, Keluarga Dan Masyarakat Dalam Mastuhu Dinamika Sistem Pendidikan Pesantren, Jakarta: Inis, 1994

Anthony Giddes, Runaway World. Bagaimana Globalisasi Merombak Kehidupan Kita. Terj Andry Kristiawan Dan Yustina Koen S. Jakarta Pustaka Utama, 2001

Azyumardi azra.Pendidikan islam: tradisi dan modernisasi menuju milenium baru. Jakarta. logos. 1999,

Djohar.Pengantar transformatif teras. Yogyakarta, 2008

Haidar putra daulay.Pendidikan Islam Dalam Sistem Pendidikan Nasional Di Indonesia. Jakarta. kencana. 2004

Karel A Steenbrink. Pesantren, Madrasah, Sekolah: Pendidikan Islam Dalam Kurun Moderen. Jakarta Lp3es. 1994..

M Ibad El-Mun'im.Daurah Ulama Dan Penguatan Peran Pesantren Dalam Bina Pesantren Media Informasi \& Artikulasi Dunia Pesantren. Edisi 01/Tahun 1/ Oktober 2006

Mashudi Abdurrahman. Memelihara Tradisi Memperbaharui Pendidikan Pesantren Dalam Bina Pesantren Media Informasi \& Artikulasi Dunia Pesantren, Edisi 01/Tahun 1/ Oktober 2006

Muhtarom,. Reproduksi Ulama Di Era Globalisasi, Pustaka Pelajar, Yogyakarta, 2005

Mundzier Suparta. Revitalisasi Pesantren: Pasang Surut Peran Dan Fungsi. Dalam Bina Pesantren Media Informasi \& Artikulasi Dunia Pe- 
106

NUANSA Vol. XII, No. 1, Juni 2019

santren. Edisi 02/Tahun 1/Nopember 2006

Ngatawi El-Zastrow. Dialog Pesantren. Barat Sebuah Transformasi Dunia Pesantren Dalam Jurnal Pondok Pesantren Mihrab Komunikatif Dalam Berwacana. Edisi 1 Tahun Iv 2006

Nurcholis Madjid, Islam Kerakyatan Dan Keindonesiaan, Cet Ke-3, Mizan, Bandung, 1996
Samsul nizar.Sejarah pendidikan islam menelusuri jejak sejarah pendidikan era rasulullah sampai indonesia. Jakarta, kencana. 2009

Sri andri astuti, Pesantren Dan Globalisasi Jurnal Tarbawiyah volume 11 nomor 1 edisi januari-juli 2015

Zamakhsyari Dhofier. Tradisi Pesantren: Studi Tentang Pandangan Kyai. Jakarta. Lp3es. 1982 